Basyiroh, A.N., \& Yuniarti, W.Y., (2020). Applying art therapy in improving resilience in child victims of domestic violence. Indigenous: Jurnal Ilmiah Psikologi, 5(2). 119-130. doi: https://doi. org/ 10.23917/indigenous.v5i2.9812

\title{
Applying Art Therapy in Improving Resilience in Child Victims of Domestic Violence
}

\author{
Arifah Nur Basyiroh ${ }^{1}$, Kwartarini Wahyu Yuniarti ${ }^{2}$ \\ Fakultas Psikologi, Universitas Gadjah Mada ${ }^{1,2}$ \\ arifah.bsy@gmail.com ${ }^{1}$, arifah.bsy@gmail.com ${ }^{2}$
}

\begin{abstract}
Domestic violence experienced by children make them more prone to emotional, behavior, adaptation and mental health problems. Some researches show that children with high resiliency are able to develop a positive attitude, perspective and adaptability despite a history of violence. The purpose of this study was to determine the effect of CBT Art Therapy intervention to increase the resiliency of children expose to domestic violence. The method used in this research is single case single-subject experiment $A B A$ design. Resilience measurement instruments used in this research are Quotient Test (RQT) and resilience behavior observation sheet. Data were analyzed through visual analysis and descriptive data analysis. The results showed an increasing score in RQT (27 points) as well as the intensity of resilience behavior and positive changes in the use of color, quality and theme of the artwork.
\end{abstract}

Keywords: art therapy; child victims of domestic violence; resilience; singlecase single-subject experiment.

\section{INTRODUCTION}

A child should ideally grow in a conducive family situation but there are some children expose to domestic violence. Such forms of abuse of domestic violence include physical, sexual, psychological and / or abuses that occur within the household (Law of the Republic of Indonesia Number 23 on Elimination of Domestic Violence [Undang-Undang Republik Indonesia Nomor 23 tentang Penghapusan Kekerasan dalam Rumah Tangga], 2004: World Health Organization, 2012).

The incidence of domestic violence in Indonesia is increased by year. In 2015 there are 11,207 cases of domestic violence both on the wife and children (Komisi Nasional Anti Kekerasan Terhadap Perempuan, 2016), increased compare to the number of cases in 2014 those are 8,626 (Komisi Nasional Anti Kekerasan Terhadap Perempuan, 2015). In addition to that, incomprehensive treatment for the victims of domestic violence may ca119use cycle of violence (Afandi et al., 2012). The victims of domestic violence may experience psychological problems such as depression, posttraumatic stress disorder (PTSD) anxiety, insomnia, and suicidal ideation (Alejo, 2014; Job et al., 2013; Holt et al., 2008; Hegarty, 2011; World Health Organization, 2012).

Psychological problems are also experienced by children who are exposed to domestic violence such as experiencing trauma (Kaur \& Garg, 2008, Lamers-Winkelman et al., 2012), developing distorted thinking patterns such as catastrophizing (Bloom, 2010), self-blame (Cunningham \& Baker, 2007) due to the egocentric mind-set of children (Holt et al., 2008; Vernon, 2009); children may blame themselves for the conflict of their parent (Edleson et al., 2007). These children are 
overwhelmed by sadness, anger (Evans et al., 2008), anxiety and depression (Black \& Hawks, 2009); have an unstable emotions (Stirling et al., 2008), difficult to empathize (Holt et al., 2008; Howell, 2011) and emotional resistance to disconnect from negative memory (Margolin \& Vickerman, 2007).

According to physiological examination, the stress of violence exposure may affect the neuropsychological condition of the children such as a fluctuation in cortisol levels and functional change on pituitary gland activity (Stirling et al., 2008; Lokhmatkina et al., 2013). High levels of cortisol and catecholamines as the body's response to stress damaged brain tissue and disrupt brain function then may lead to decreased of memory and concentration (Black \& Hawks, 2009), as well as problems in children's behavior development (Al Odhayani et al., 2013). Violent exposure also changes the cortex structure of the child correlate with social function, empathy ability and susceptible to psychopathology (Kelly et al., 2013).

The behavior of children exposed to domestic violence indicates low social ability such as withdrawal (Herrenkohl et al., 2008), difficulty getting along with others (Kent et al., 2017; Wood et al., 2009), low self-esteem (Ernst et al., 2009); Pessimistic, low concentration, learning difficulties (Rajendran, 2008) and low academic performance (Holt et al., 2008), susceptible to anxiety, sleep disorders (Ernst et al., 2009) aggressive bahvior (Moylan et al., 2010). The longterm impacts such as more likely to experience depression or aggressive behavior in adolescence (Moylan et al., 2010); Become a teenager with low self-esteem (Young \& Widom, 2014); Selfinjury (Armiento et al., 2016); social withdrawal (Al Odhayani et al., 2013); drug and alcohol abuse in adulthood (Lansford et al., 2007); Being a perpetrator (Ernst et al., 2009); difficulties to have close relationships with others (Kent et al., 2017); Even personality disorders (Afifi et al., 2011).

Children exposed to domestic violence can avoid negative effects if they are able to adapt to stress (Edleson et al., 2007; Zolkoski \& Bullock, 2012). A person's ability to adapt in the midst of adversity and stress is called resiliency (Reivich \& Shatte, 2002; Howell, 2011; Prince-Embury \& Saklofske, 2012). Resiliency comes from the Latin word resilire which means bouncing (Masten, 2014). Factors that affect resiliency in children are intelligency (Herrenkohl et al., 2008; MartinezTorteya et al., 2009), coping skills (Rutter, 2007), temperament, gender, age (Lamers-Winkelman et al., 2012) execution and motivation functions (Masten, 2014). In addition, a number of external factors also affect the ability of children's resilience. These external factors include parenting patterns, exposure to violence (Ebach et al., 2013), school and environment conditions (Artz \& Nicholson, 2010), culture and involvement in religious activities (Herrenkohl et al., 2008; Masten, 2014).

Increased resilience can also be done through art therapy. Art therapy helps to release stress in children because it can help children to express emotions that are difficult to express verbally (Cristina \& Aneta, 2012) as well as providing a safe distance between children with emotions (Abdallah, 2009). (Folostina et al., 2015) uses drama and drama art therapy to improve the resilience of vulnerable children (due to poverty, poor supervision, abuse and abuse, children with chronic illness), the study also uses the image media to check the level of child resilience.

Art therapy approach essentially aids the healing process because the creative process has a healing effect, improves the quality of life and facilitates the communication of thoughts and feelings non-verbally (Malchiodi, 2003). The Art Therapy in this research uses Cognitive Behavior Therapy (CBT) approach as the approach is considered to be able to support measurable behavior changes (Hanson, 2013). The process of expression in art therapy with CBT approach can reduce negative emotions and cognitive distortions because it can access the child's memory and emotions in a non-scary way (Hanson, 2013) with the steps that are based on 4 core problems: self-image, 
emotion, interaction and Cognition (Smeijsters et al., 2011).

Research of Art therapy with CBT approach for child victims of domestic violence ever done by Puspitasari (2015) for the child victims of domestic violence who experienced PTSD. The results showed the child's ability to excite negative emotions, decreased avoidance behavior toward sources of stressors or figures that resemble and descend anxiety and explosive emotions. In Septiani's research (2015) it is showed that CBT Art Therapy intervention can significantly decrease aggressiveness intention and reduced the frequency of aggressive behavior.

The CBT Art Therapy Intervention used in this research is the development of Art Therapy Intervention Module for Children Victims of Domestic Violence compiled by Erawan et al. (2015). The research begins with a preliminary session of building rapport and emotional recognition. The activity continued with a number of sessions referring to three basic aspects of CBT: make an image of a stressor, restructuring the negative and cognitive reframing. The therapist plays an important role in giving feedback to the discussion session with the subject through "the miracle questions" which in the CBT approach known as the challenging mind technique (Longmore \& Worrell, 2007; Cully $\&$ Teten, 2008) so the subject can practice an alternative thinking skill. Modifications to the previous module are done by simplifying the instruction and applying multimodal art medium those are drawing and sculpting.

The art therapy intervention in this study aimed to increase the resiliency of child victims of domestic violence. Stages of intervention which are believed to support the formation of resiliency such as the stage of "Make an Image of A Stressor" that aims to improve causal analysis to help children recognize themselves and make preparations for unpleasant situations so as to form efficacy and self-esteem that by Rizo et al. (2011) is considered to support the fostering of child resiliency; the "Negative Restructuring" stage children are encouraged to be sensitive to their thoughts, emotions and their influence on maladaptive behavior. This stage prepares the children for the cognitive reframing stage so the children are able to find problem solving strategies, improve the ability to empathize and reaching out with regard to the ability to self-regulation, pro-social and optimistic thinking.

The art therapy intervention in this study is presented individually to have an intensive interaction with the subject and to make sure that the therapy is provided in accordance with the readiness and needs of the subject. The hypothesis that will be proven in this research is that The CBT Art Therapy can effectively improve the resilience of child victims of domestic violence.

\section{METHOD}

\section{Subject}

A 9 year old boy. Who experienced (KDRT) in the form of punches, pinches and sabetan from his mother for \pm 2 years, previously had witnessed verbal violence and emotions father against his mother. Aggressive behavior increased after watching the police arrest his father at home 2 years ago. Subject Has behavioral problems that lead to moderate resilience levels.

\section{Instruments}

Effects of The Art Therapy module is measured by Resilience Quotient Test that refers to the theory of Reivich \& Shatté. According to Reivich \& Shatté (2002) resilience has seven aspects: emotional regulation, impulse control, optimism, causal analysis, empathy, self efficacy, and reaching out. The RQT scale in this study is a modification of the Indonesian adaptation RQT scale compiled by Suwarjo (2008). 


\section{Research Design}

This research uses single-case ABA design single-subject experiments beginning with initial baseline condition (A) that is normal behavior without treatment, then giving manipulation or treatment (B) as independent variable and then observing behavior change by eliminating independent variable Then returns to baseline condition (A) to determine the effect of treatment given (Myers \& Hansen, 2011; Wilmhurst, 2012).

Table 1.

Research Design

\begin{tabular}{ccc}
\hline Baseline (A) & Treatment (B) & Baseline (B) \\
\hline $\mathrm{A}_{1} \mathrm{~A}_{2} \mathrm{~A}_{3} \mathrm{~A}_{4} \mathrm{~A}_{5}$ & $\mathrm{~B}_{1} \mathrm{~B}_{2} \mathrm{~B}_{3} \mathrm{~B}_{4} \mathrm{~B}_{5} \mathrm{~B}_{6} \mathrm{~B}_{7} \mathrm{~B}_{8} \mathrm{~B}_{9} \mathrm{~B}_{10}$ & $\mathrm{~A}_{1} \mathrm{~A}_{2} \mathrm{~A}_{3} \mathrm{~A}_{4} \mathrm{~A}_{5}$ \\
\hline
\end{tabular}

$\mathrm{A}_{1-5}=$ initial baseline (subject's level of resiliency); $\mathrm{B}=$ treatment (10 sessions CBT Art Therapy); $\mathrm{A}_{1-5}=$ baseline subject's resiliency level after treatment.

\section{Research Procedures}

Research begins by modifying and selecting a scale of RQT. The scale contains 56 items with correlation correlation correlation coefficient (corrected item-total correlation) moving from 0.277 to 0.687 and Alpha Cronbach coefficient of 0.933 which means having good validity and reliability. The results of the research intervention were also analyzed qualitatively with the artwork analysis of observing changes in the subject image results during the intervention.

Adjustment of instrument language is done to meet the age range characteristics of the research subjects. The process of language adjustment includes the assessment of the difficulty level of sentences by 3 children aged 8-11 years and input 14 people with educational background S2 psychology who understand the concept of psychology scale. The modified scales were tested in 159 children aged 9-12 years from the vulnerable environment of domestic violence. The aitem selection uses the standard corrected item-total correlation> 0.25 . There are 28 remaining RQT items and the Alpha Cronbach coefficient of 0.811 is obtained. Administration RQT done in a way read given the condition of subjects who have not been able to read smoothly, the subject answered using visual stimulation assistance in the form of smiley.

Modification of modules is done by adding sculpturing techniques using plastisin media to ease emotional tension at sessions that address the subject stressor source. The addition of techniques and media art done without changing the aspects of the module that is Make An Image of A Stressor, Restructuring The Negative, and Cognitive Reframing. The modified module has been assessed by 4 rater as a clinical psychologist and 1 rater is a counselor of the Women's Empowerment, Child Protection \& Family Planning Board and has conducted research on art therapy. Assessment of the rater is then processed statistically resulting in an interclass correlation coefficient of 0.980 .

Research subjects were children aged 9-12 years who had a tendency of low-moderate resilience behavior due to experiencing domestic violence and had never received psychological treatment. Initial screening results at NGO S indicated there were 3 children who met the criteria but only 1 child got consent approval to get immediate psychological intervention art therapy.

\section{RESULTS AND DISCUSSION}

The results of this research can be seen from the subject's artwork which are analyzed 
qualitatively by the visual analyzis while subject's cognitive and behaviour changes are analyzed by the descriptive data analyzis and the changes in subject's resiliency level is measured by the RQT.

\section{Drawings Transformation}

Subject initially draw in black color only, images with colors other than black are made on separate side. Furth (2002) mentions that black color symbolizes ignorance, the use of excessive black color indicates a negative connotation. Physical violence from the mother coupled with the emptiness of separation from the father and the rejection of the environment can make the subject overwhelmed with emotions or negative thoughts. In the next picture the black color is no longer dominant and the color giving according to the real object color.

The subject's drawing is difficult to understand because it has different character from the original object. Subject draws in scribbling and basic form quality without any details. Malchiodi (1998) mentions that children who are exposed to violence solve the picture quickly but pay less attention to detail, image integration and composition in other words the expression of the art is shallow, stereotyped or scribble.

Subject shows excessive shading strokes in session 3, 5 and 7. Furth (2002) defines black shading as negative, symbolizing the dark side of the mind, a threat or fear. Epperson in Malchiodi (1998) explains that children who are exposed to violence often make shading because it makes them feel good. Excessive shading making is often used as a means of self-soothing (Malchiodi, 1997). The quality of the subject's drawing develops in the session 7 shows the face detail on the person's figure. Significant changes that can be observed in the subject's drawings are the use of color, themes and image quality seen in the image 1.

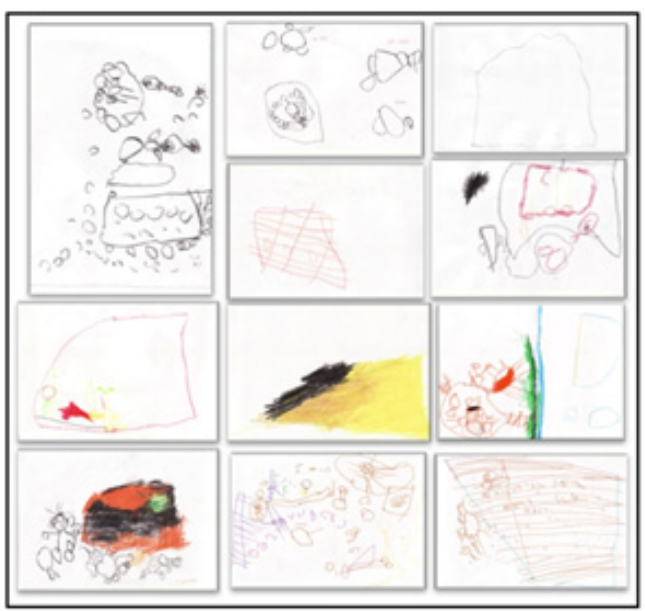

Image 1 .

Subject's Drawing Transformation during Intervention

a) Subject's drawing of session 1; b \& c) Subject's drawing of session 2;

d \& e) Subject's drawing of session 3; f) Subject's drawing of session 4;

g) Subject's drawing of session 5; h) Subject's drawing of session 6;

i) Subject's drawing of session 7; and j \& k) Subject's drawing of session 8.

Subject image themes often contain elements of violence. Malchiodi (1998) mentions that violence-themed images often reveal certain issues and feelings that children experience. Drawings in sessions 6 and 7 show more positive activity than previous drawings. Children who experience domestic violence but show a positive aspect on the image that he made indicates the characteristics of resilience (Malchiodi, 1998). 


\section{Changes in behaviour: Pre-intervention behavior}

Subject has lack impulse control and often showing aggressive behavior. He also has less consideration of the consequences of their actions. Subject do not want to admit mistakes, reluctant to make up and show hostility toward people he hates. Greenspan \& Woods (2014) states that children with intellectual disabilities have limited reasoning abilities to deal with everyday situations. The cause of intellectual disability is caused by environmental conditions such as problematic birth (Maerlender, 2004) as experienced by the subject.

\section{Behavior During Intervention}

Subject with intellectual obstacles did not experience significant problems during followup interventions of CBT. Greenspan \& Woods (2014) explains that children with intellectual disabilities experience obstacles in reasoning ability and thinking rather than learning ability so that they can be equipped with concrete skills through behavior modification method. The application of CBT to intellectual disability children focuses on emotion recognition and cognitive restructuring (Wood et al., 2009) to modify cognitive distortions that affect presenting problems (Taylor et al., 2008). It's just that the subject has a high physical activity needs and easily bored so that variations of techniques and media art done in order to overcome the blocking conditions.

\section{Post-Intervention Behavior}

Subject exhibit behavioral developments such as increased ability of emotional regulation and impulse control even though the development of causal analysis capabilities or reasoning is less than optimal. The reasoning ability involves the frontal lobe area in the cerebral part of the brain (Damasio et al., 2004). Subject have a history of hypoxia because the airway is closed amniotic fluid at birth and seizures when aged 4 years are likely to result in brain injury. Brain injury in the neonatal occurs due to a lack of blood supply containing oxygen to the brain, one of the causes is hypoxia (Huang \& Castillo, 2008).

\section{Changes in Resilience Behavior}

Measurements using resilience scale showed a change in RQT score of 27 points from a score of 75 (medium resilience) to 102 (medium resilience). From the results mentioned above, subject's RQT scale measurement shows 27 points increase as well as the visual graph which shows resilience behavior increasing after the intervention phase. The descriptive data also shows the increase of emotional regulation and impulse control skill. The artwork analysis also indicate an increase in resilience behavior from the colorful artworks and positive story theme in the last 3 sessions.

\section{CONCLUSION}

Results of this research show that the CBT Art Therapy can effectively be applied to help raise resiliency level in children victim of domestic violence. This research had modify the RQT scale and CBT Art Therapy Intervention module so it has more simple instruction and use multimodal technique to help the double handicapped subject (victims of domestic violence and classified as intellectually defective). Things that need to be considered in the establishment of CBT Art Therapy intervention for double handicapped children is the focus on the process of emotion recognition, cognitive restructuring and the role of the therapist in helping the subjects to find their core belief or automatic thoughts since the subjects' condition may impede them to do it independently.

Further research are expected to be able to develop art therapy module that can be presented 
by non-psychologist such as teacher, social worker or related parties that are handling child problems. For psychologists, it is necessary to establish cooperation and make programs to improve the skills of handling problems in children such as art therapy for the facing parties directly dealing with children such as parents, teachers and social workers. Psychologists can also work with artists to enrich the techniques used in art therapy interventions.

For Non-Psychologist Professionals, the basics of image and color meanings need to be known by teachers and parents so that they can see children's work with a broader perspective. The CBT Art Therapy module for double handicapped children is expected to help improve the capacity of non-psychologist professionals such as inclusive school teachers, special education teachers and social workers in understanding and handling double handicapped children especially those experiencing domestic violence.

\section{REFERENCES}

15 year old boy's creative journey (Research paper; Concordia University, Quebec, Canada). Retrieved from https://spectrum.library.concordia.ca/976545/ on June 3, 2020.

Afandi, D., Rosa, W. Y., Suyanto, Khodijah, \& Widyaningsih, C. (2012). Karakteristik kasus kekerasan dalam rumah tangga. Journal of the Indonesian Medical Association, 62(11), 435-438. Retrieved from http://fk.unri.ac.id/wp-content/uploads/2017/11/KarakteristikKDRT-2012.pdf on June 3, 2020.

Afifi, T. O., Mather, A., Boman, J., Fleisher, W., Enns, M. W., MacMillan, H., \& Sareen, J. (2011). Childhood adversity and personality disorders: Results from a nationally representative population-based study. Journal of Psychiatric Research, 45(6), 814-822. https://doi. org/10.1016/j.jpsychires.2010.11.008

Al Odhayani, A., Watson, W. J., \& Watson, L. (2013). Behavioural consequences of child abuse. Canadian Family Physician, 59(8), 831-836. Retrieved from https://www.ncbi.nlm.nih. gov/pmc/articles/PMC3743691/ on June 3, 2020.

Alejo, K. (2014). Long-term physical and mental health effects of domestic violence. Themis: Research Journal of Justice Studies and Forensic Science, 2(1), 82-98. Retrieved from https:// scholarworks.sjsu.edu/themis/vol2/iss 1/5/ on June 3, 2020.

Armiento, J., Hamza, C. A., Stewart, S. L., \& Leschied, A. (2016). Direct and indirect forms of childhood maltreatment and nonsuicidal self-injury among clinically-referred children and youth. Journal of Affective Disorders, 200, 212-217. https://doi.org/10.1016/j. jad.2016.04.041

Artz, S., \& Nicholson, D. (2010). Reducing aggressive behavior in adolescent girls by attending to school climate. Fighting for Girls: New Perspectives on Gender and Violence, 149-173. Retrieved from https://www.researchgate.net/publication/287458318_Reducing aggressive_behavior_in_adolescent_girls_by_attending_to_school_climate on June 3, 2020.

Black, J. M., \& Hawks, J. H. (2009). Medical-surgical nursing: Clinical management for positive outcomes (8th ed.). Saunders Elsvier. Retrieved from https://www.amazon.com/MedicalSurgical-Nursing-Clinical-Management-Positive/dp/1416036415 on Jue 3, 2020. 
Bloom, S. L. (2010). Mental health aspects of IPV/DV: Survivors, professionals, and systems. Originally published in Giardino AP \& Giardino ER (Eds.), Intimate partner violence, domestic violence, spousal abuse: A resourch for professionals working with children and families (pp.1-38) [GW Medical Publishing version]. Retrieved from http://www.sanctuaryweb. com/Portals/0/Bloom Pubs/2010 Bloom Mental Health Aspects of IPV.pdf on June 3, 2020.

Cristina, C., \& Aneta, F. (2012). How can we improve the existing assessments used in arttherapy. A meta-analysis on art therapy assesments. Procedia - Social and Behavioral Sciences, 33, 358-362. https://doi.org/10.1016/j.sbspro.2012.01.143

Cully, J. A., \& Teten, A. L. (2008). A therapist's guide to brief cognitive behavioral therapy [MIRECC version]. Retrieved from https://www.mirecc.va.gov/visn16/docs/therapists_guide_to_ brief_cbtmanual.pdf on June 3, 2020.

Cunningham, A. J., \& Baker, L. L. (2007). Little eyes, little ears: How violence against a mother shapes children as they grow. Centre for Children \& Families in the Justice System (London Family Court Clinic, Inc.). Retrieved from https://books.google.co.id/books/about/Little_Eyes_ Little_Ears.html?id=g9ViPwAACAAJ\&redir_esc=y on June 3, 2020.

Damasio, A. R., Damasio, H., \& Christen, Y. (2004). Neurobiology of Decision-Making (A. R. Damasio, H. Damasio, \& Y. Christen (Eds.). [Springer Verlag version]. https://doi. org/10.1007/978-3-642-79928-0

Ebach, M. C., Gill, A. C., Kwan, A., Ahyong, S. T., Murphy, D. J., \& Cassis, G. (2013). Towards an Australian bioregionalisation Atlas: A provisional area taxonomy of Australia’s biogeographical regions. Zootaxa, 3619(3), 315-342. https://doi.org/10.11646/zootaxa.3619.3.4

Edleson, J. L., Ellerton, A. L., Seagren, E. A., Kirchberg, S. L., Schmidt, S. O., \& Ambrose, A. T. (2007). Assessing child exposure to adult domestic violence. Children and Youth Services Review, 29(7), 961-971. https://doi.org/10.1016/j.childyouth.2006.12.009

Erawan, G. N., Septiani, Y. A., \& Puspitasari, P. M. (2015). Modul program art therapy bagi anak korban kekerasan dalam rumah tangga (Thesis not published). Magister Profesi Psikologi Universitas Gadjah Mada, Yogyakarta.

Ernst, A. A., Weiss, S. J., Hall, J., Clark, R., Coffman, B., Goldstein, L., Hobley, K., Dettmer, T., Lehrman, C., Merhege, M., Corum, B., Rihani, T., \& Valdez, M. (2009). Adult intimate partner violence perpetrators are significantly more likely to have witnessed intimate partner violence as a child than nonperpetrators. The American Journal of Emergency Medicine, 27(6), 641-650. https://doi.org/10.1016/j.ajem.2008.05.003

Evans, S. E., Davies, C., \& DiLillo, D. (2008). Exposure to domestic violence: A meta-analysis of child and adolescent outcomes. Aggression and Violent Behavior, 13(2), 131-140. https:// doi.org/10.1016/j.avb.2008.02.005

Folostina, R., Tudorache, L., Michel, T., Erzsebet, B., Agheana, V., \& Hocaoglu, H. (2015). Using play and drama in developing resilience in children at risk. Procedia-Social and Behavioral Sciences, 197, 2362-2368. https://doi.org/10.1016/j.sbspro.2015.07.283 
Furth, G. M. (2002). The secret world of drawings: A jungian approach to healing through art (2nd ed.). Boston, Massachusetts: Sigo Press.

Greenspan, S., \& Woods, G. W. (2014). Intellectual disability as a disorder of reasoning and judgement: The gradual move away from intelligence quotient-ceilings. Current Opinion in Psychiatry, 27(2), 110-116. https://doi.org/10.1097/YCO.0000000000000037

Hanson, A. (2013). The use of art therapy and cognitive behavioral therapy to address trauma symptoms in hospitalized children (Thesis; Adler Graduate School, Minnetonka, Minnesota). Retrieved from https://alfredadler.edu/library/masters/2013/anneliese-hanson on June 3, 2020.

Hegarty, M. (2011). The cognitive science of visual-spatial displays: Implications for design. Topics in Cognitive Science, 3(3), 446-474. https://doi.org/10.1111/j.1756-8765.2011.01150.x

Herrenkohl, T. I., Sousa, C., Tajima, E. A., Herrenkohl, R. C., \& Moylan, C. A. (2008). Intersection of child abuse and children's exposure to domestic violence. Trauma, Violence, \& Abuse, 9(2), 84-99. https://doi.org/10.1177/1524838008314797

Holt, S., Buckley, H., \& Whelan, S. (2008). The impact of exposure to domestic violence on children and young people: A review of the literature. Child Abuse \& Neglect, 32(8), $797-$ 810. https://doi.org/10.1016/j.chiabu.2008.02.004

Howell, K. H. (2011). Resilience and psychopathology in children exposed to family violence. Aggression andViolent Behavior, 16(6), 562-569. https://doi.org/10.1016/j.avb.2011.09.001

Huang, B. Y., \& Castillo, M. (2008). Hypoxic-ischemic brain injury: Imaging findings from birth to adulthood. RadioGraphics, 28(2), 417-439. https://doi.org/10.1148/rg.282075066

Job, V., Walton, G. M., Bernecker, K., \& Dweck, C. S. (2013). Beliefs about willpower determine the impact of glucose on self-control. Proceedings of the National Academy of Sciences, 110(37), 14837-14842. https://doi.org/10.1073/pnas.1313475110

Kaur, R., \& Garg, S. (2008). Addressing domestic violence against women: An unfinished agenda. Indian Journal of Community Medicine, 33(2), 73-76. https://doi.org/10.4103/09700218.40871

Kelly, W., Garcia, P., McDermott, S., Mullen, P., Kamguia, G., Jones, G., Ubiera, A., \& Göklen, K. (2013). Experimental characterization of next-generation expanded-bed adsorbents for capture of a recombinant protein expressed in high-cell-density yeast fermentation. Biotechnology and Applied Biochemistry, 60(5), 510-520. https://doi.org/10.1002/bab.1133

Kent, J. A., Stergiou, N., \& Wurdeman, S. R. (2017). Dynamic balance changes within three weeks of fitting a new prosthetic foot component. Gait \& Posture, 58, 23-29. https://doi. org/10.1016/j.gaitpost.2017.07.003

Komisi Nasional Anti Kekerasan Terhadap Perempuan. (2015). Kekerasan terhadap perempuan: Negara segera putus impunitas pelaku. Retrieved from https:/www.komnasperempuan. go.id/file/pdf_file/Catatan Tahunan/13.PP5_CATAHU-2015.pdf on June 3, 2020

Komisi Nasional Anti Kekerasan Terhadap Perempuan. (2016). Kekerasan terhadap perempuan meluas: Negara urgen hadir hentikan kekerasan terhadap perempuan di ranah domestik, 
komunitas dan negara. Retrieved from https://www.komnasperempuan.go.id/file/pdf_file/ Catatan Tahunan/14.PP5_CATAHU 2016.pdf on June 3, 2020.

Lamers-Winkelman, F., Willemen, A. M., \& Visser, M. (2012). Adverse childhood experiences of referred children exposed to intimate partner violence: consequences for their wellbeing. Child Abuse \& Neglect, 36(2), 166-179. https://doi.org/10.1016/j.chiabu.2011.07.006

Lansford, J. E., Miller-Johnson, S., Berlin, L. J., Dodge, K. A., Bates, J. E., \& Pettit, G. S. (2007). Early physical abuse and later violent delinquency: a prospective longitudinal study. Child Maltreatment, 12(3), 233-245. https://doi.org/10.1177/1077559507301841

Lokhmatkina, N. V, Feder, G., Blake, S., Morris, R., Powers, V., \& Lightman, S. (2013). Longitudinal measurement of cortisol in association with mental health and experience of domestic violence and abuse: Study protocol. BMS Psychiatry, 13, 1-8. Retrieved from https://core.ac.uk/download/pdf/81604994.pdf on June 3, 2020.

Longmore, R. J., \& Worrell, M. (2007). Do we need to challenge thoughts in cognitive behavior therapy? Clinical Psychology Review, 27(2), 173-187. https://doi.org/10.1016/j. cpr.2006.08.001

Maerlender, A. (2004). The Wechsler intelligent scale for children [Hardcourt Assesment, Inc version. https://doi.org/10.1007/978-0-387-79061-9_3066

Malchiodi, C. A. (1997). Breaking the silence: Art therapy with children from violent homes (2nd, Revised ed.) [Brunner-Routledge (Taylor \& Francis Group) version]. Retrieved from https://www.amazon.com/Breaking-Silence-Therapy-Children-Violent/dp/0876308248 on June 3, 2020.

Malchiodi, C. A. (1998). Understanding children's drawings [Guilford Press version]. Retrieved from https://books.google.co.id/books/about/Understanding_Children_s_Drawings. html?id=NMmF6OdXnTAC\&redir_esc=y on June 3, 2020.

Malchiodi,C.A. (2003). Handbookofarttherapy[GuilfordPressversion]. Retrievedfrom https://books. google.co.id/books/about/Handbook_of_Art_Therapy.html?id=4hXZEJCb4ooC\&redir_ esc=y on June 3, 2020.

Margolin, G., \& Vickerman, K. A. (2007). Post-traumatic stress in children and adolescents exposed to family violence: I. Overview and issues. Professional Psychology, Research and Practice, 38(6), 613-619. https://doi.org/10.1037/0735-7028.38.6.613

Martinez-Torteya, C., Anne Bogat, G., Von Eye, A., \& Levendosky, A. A. (2009). Resilience among children exposed to domestic violence: The role of risk and protective factors. Child Development, 80(2), 562-577. https://doi.org/10.1111/j.1467-8624.2009.01279.x

Masten, A. S. (2014). Global perspectives on resilience in children and youth. Child Development, 85(1), 6-20. https://doi.org/10.1111/cdev.12205

Moylan, C. A., Herrenkohl, T. I., Sousa, C., Tajima, E. A., Herrenkohl, R. C., \& Russo, M. J. (2010). The effects of child abuse and exposure to domestic violence on adolescent internalizing and externalizing behavior problems. Journal of Family Violence, 25(1), 53-63. https://doi. org/10.1007/s10896-009-9269-9 
Myers, A., \& Hansen, C. H. (2011). Experimental psychology (7th ed.) [Cengage Learning version]. Retrieved from https://books.google.co.id/books/about/Experimental_Psychology. html?id=AZgFmMqpWTUC\&redir_esc=y on June 3, 2020.

Prince-Embury, S., \& Saklofske, D. H. (2012). Resilience in children, adolescents, and adults: Translating research into practice [Springer Science \& Business Media version]. Retrieved from https://books.google.co.id/books/about/Resilience_in_Children_Adolescents_ and_A.html?id=eBZ4zzBfJqoC\&redir_esc=y on June 3, 2020.

Puspitasari, P. M. (2015). Penerapan art therapy pada anak korban kekerasan dalam rumah tangga disertai gejala gangguan stress pasca trauma (Thesis; Universitas Gadjah Mada, Yogyakarta, Indonesia. Retrieved from http://etd.repository.ugm.ac.id/penelitian/detail/89300 on June 3, 2020.

Rajendran, K. (2008). Impact of relationship with the caregiver and positive future expectations on behavioral and emotional resilience in adolescents in child welfare (Dissertation, University at Albany, Albany, New York). Retrieved from http://citeseerx.ist.psu.edu/viewdoc/ download?doi=10.1.1.548.5599\&rep=rep1\&type=pdf on June 3, 2020.

Reivich, K., \& Shatte, A. (2002). The resilience factor: 7 keys to finding your inner strength and overcoming life's hurdles [Three Rivers Press version]. Retrieved from https://books.google. co.id/books/about/The_Resilience_Factor.html?id=Ons_LmZYdyQC\&redir_esc=y on June 3, 2020.

Rizo, C. F., Macy, R. J., Ermentrout, D. M., \& Johns, N. B. (2011). A review of family interventions for intimate partner violence with a child focus or child component. Aggression and Violent Behavior, 16(2), 144-166. https://doi.org/10.1016/j.avb.2011.02.004

Rutter, M. (2007). Resilience, competence, and coping. Child Abuse \& Neglect, 31(3), 205-209. https://doi.org/10.1016/j.chiabu.2007.02.001

Septiani, Y. A. (2015). Art therapy berbasi CBT untuk menurunkan agresivitas anak korban kekerasan dalam rumah tangga (Thesis; Universitas Gadjah Mada, Yogyakarta, Indonesia). Retrieved from http://etd.repository.ugm.ac.id/penelitian/detail/89133 on June 3, 2020.

Smeijsters, H., Kil, J., Kurstjens, H., Welten, J., \& Willemars, G. (2011). Arts therapies for young offenders in secure care-A practice-based research. The Arts in Psychotherapy, 38(1), 4151. https://doi.org/10.1016/j.aip.2010.10.005

Stirling, J., Amaya-Jackson, L., \& Amaya-Jackson, L. (2008). Understanding the behavioral and emotional consequences of child abuse. Pediatrics, 122(3), 667-673. https://doi. org/10.1542/peds.2008-1885

Suwarjo. (2008). Pedoman konseling teman sebaya untuk pengembangan resiliensi (Dissertation; Universitas Pendidikan Indonesia, Bandung, Indonesia]. Retrieved from http://staff.uny. ac.id/sites/default/files/pendidikan/Suwarjo, M.Si., Dr. /Pedoman Pengembangan Peer Counsseling.pdf on June 3, 2020.

Taylor, J. L., Lindsay, W. R., \& Willner, P. (2008). CBT for people with intellectual disabilities: Emerging evidence, cognitive ability and IQ effects. Behavioural and Cognitive Psychotherapy, 
36(6), 723-733. https://doi.org/10.1017/S1352465808004906

Undang-Undang Republik Indonesia Nomor 23 tentang Penghapusan Kekerasan dalam Rumah Tangga. (2004). Undang-Undang Republik Indonesia Nomor 23 tentang Penghapusan Kekerasan dalam Rumah Tangga. Retrieved from http://hukum.unsrat.ac.id/uu/uu_23_04. htm on June 3, 2020.

Vernon, A. (2009). Counseling children and adolescents (4th ed.) [Love Publishing Company version]. Retrieved from https://www.amazon.com/Counseling-Children-AdolescentsAnn-Vernon/dp/0891083405 on June 3, 2020.

Wilmshurst, L. (2012). Clinical and educational child psychology: An ecological-transactional approach to understanding child problems and interventions (1st ed.) [John Wiley \& Sons version]. Retrieved from https://www.amazon.com/Clinical-Educational-Child-PsychologyEcological-Transactional-ebook/dp/B00BG4EI34 on June 3, 2020.

Wood, J. J., Drahota, A., Sze, K., Har, K., Chiu, A., \& Langer, D. A. (2009). Cognitive behavioral therapy for anxiety in children with autism spectrum disorders: A randomized, controlled trial. Journal of Child Psychology and Psychiatry, 50(3), 224-234. https://doi.org/10.1111/ j.1469-7610.2008.01948.x

World Health Organization. (2012). Understanding and addressing violence against women. Retrieved from http://apps.who.int/iris/bitstream/handle/10665/77421/WHO_RHR_12.38_ eng.pdf?sequence $=1 \% 0$ Ahttp://apps. who.int/iris/bitstream/10665/77421/1/WHO_ RHR_12.38_eng.pdf on June 3, 2020.

Young, J. C., \& Widom, C. S. (2014). Long-term effects of child abuse and neglect on emotion processing in adulthood. Child Abuse \& Neglect, 38(8), 1369-1381. https://doi. org/10.1016/j.chiabu.2014.03.008

Zolkoski, S. M., \& Bullock, L. M. (2012). Resilience in children and youth: A review. Children and Youth Services Review, 34(12), 2295-2303. https://doi.org/10.1016/j. childyouth.2012.08.009 